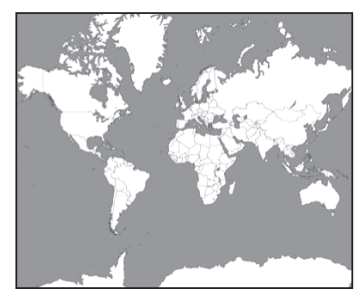

Dr Cassidy Johnson is a Lecturer at the Development Planning Unit, University College London, with a particular interest in disaster risk reduction and its integration into urban development and climate change adaptation.

Address: Bartlett Development Planning Unit, University College London, 34 Tavistock Square, London WC1H 9EZ, UK; e-mail: cassidy.johnson@ ucl.ac.uk

Sophie Blackburn is a PhD student at the Department of Geography, King's College London where she is researching on disaster governance in Tamil Nadu, South India.

Address: e-mail: sophie. blackburn@kcl.ac.uk

\section{Advocacy for urban resilience: UNISDR's Making Cities Resilient Campaign}

\author{
CASSIDY JOHNSON AND SOPHIE BLACKBURN
}

\begin{abstract}
This paper reviews what local governments in more than 50 cities are doing with regard to disaster risk reduction. It draws on the reports of their participation in the global Making Cities Resilient Campaign and its 10 "essential" components, and on interviews with city mayors or managers. These show how resilience to disasters is being conceived and addressed by local governments, especially with regard to changes in their institutional framework and engagement with communities and other stakeholders, also in mobilizing finance, undertaking multi-hazard risk assessments, upgrading informal settlements, adjusting urban planning and implementing building codes. The paper summarizes what city mayors or managers view as key milestones for building resilience, and further discusses their evaluation of the usefulness of the campaign to them. It also discusses how a local government-focused perspective on disaster risk reduction informs our understanding of resilience. This includes how development can contribute much to disaster risk reduction as well as a more tangible and operational understanding of resilience (resistance + coping capacity + recovery + adaptive capacity) that local governments can understand and act on.
\end{abstract}

KEYWORDS disaster / local government / planning / resilience / risk reduction / urban

\section{INTRODUCTION}

"Not knowing about disaster risk is a dereliction of duty. The campaign gives every city an opportunity to see itself as part of a global network to reduce disaster risk, which ought to be part of every government's core mandate. Through its various tools, resources and training events, the campaign serves an important function in raising awareness of disaster risk to both local and national levels." (Hon. Lianne Dalziel, Member of Parliament, Christchurch East, New Zealand)

The concept of resilience is used in the disasters field as a way of understanding the ability of a system to avoid damage as a result of a natural hazard impact. It has been used in reference to different scales and different kinds of systems. In recent years, it has increasingly been used to conceptualize the ideal characteristics of an urban system that can withstand natural hazard events and the direct and indirect impacts of climate change. 
A consideration of resilience with regard to cities $^{(1)}$ has been taken up by the United Nations International Strategy for Disaster Reduction (UNISDR) and adopted in their Making Cities Resilient Campaign, which began in 2010. This runs concurrently with the Hyogo Framework of Action, which seeks attention to disaster risk reduction (DRR).(2) Among global initiatives, the campaign is unusual in its focus both on urban and on local governments, which are seen as the "front line" in DRR. The campaign promotes resilience-building in cities through many mechanisms, including raising awareness of DRR among local governments through high-profile events, providing tools, technical assistance and training to local authorities and facilitating city-to-city support networks and learning opportunities. ${ }^{(3)}$

This paper reviews what local governments in more than 50 cities are reporting in response to their participation in this campaign, including the kinds of DRR activities they are involved in, how they see and assess resilience, and how they view the campaign and its utility to their work.

\section{A SHORT SUMMARY OF DOMINANT IDEAS ABOUT RESILIENCE}

At its most basic, resilience refers to the ability of a system to avoid suffering irreparable damage as a result of hazard impact. It was first used in this sense in a paper by Holling published in $1973^{(4)}$ on the ability of environmental systems to absorb impact and reorganize to regain full functionality. It has since entered the social sciences via literature on global environmental change, political ecology and disaster studies. In the literature on disasters, it is now widely accepted that "natural disasters" are the product of human processes of vulnerability creation, ${ }^{(5)}$ raising the question of what society can itself do to reduce and withstand hazard risk - i.e. increase its resilience. This concern is heightened in cities, where populations and assets are concentrated. ${ }^{(6)}$

The widespread use of the term "resilience" in high level policy circles has been attributed to its more positive and proactive connotations relative to terms such as "vulnerability" or "disaster risk reduction".(7) However, while resilience has taken hold in international policy discourse, the complexities and contradictions of its definition (and even more, agreement on its application or measurement) have yet to be resolved. ${ }^{(8)}$ Resilience may be defined as an idealized "state of being" (for instance "a resilient city") or a dynamic process through which this state of being is improved through learning and adaptation (as a governing strategy). ${ }^{(9)}$ Resilience is seen as necessary for DRR - and increasingly also for climate change adaptation.

Increasingly, definitions of resilience include an emphasis on adaptive capacity, which is, for instance, seen as a vital determinant of a resilient city and an essential response to climate change. Adaptive capacity is defined as "... the ability to plan, prepare for, facilitate and implement adaptation options",(10) and determinants include wealth, technology, infrastructure, information, knowledge and skills, commitment to equity and social capital.(11) This definition reflects the fact that not all communities, sectors and households have equal access
1. The term "city" is used in this paper primarily to include urban centres, i.e. settlements that meet the urban criteria set by their national governments or designated by them as urban centres; but it also includes other sub-national administrations of different sizes and levels, including some regional, metropolitan and provincial areas as well as municipalities and townships.

2. This is a 10-year plan running from 2005 to 2015 to build the resilience of nations and communities to disasters; it was endorsed by the UN General Assembly following the 2005 World Disaster Reduction Conference.

3. UNISDR (2012a), How to Make Cities More Resilient: A Handbook for Local Government Leaders, United Nations, Geneva, 102 pages.

4. Holling, C S (1973),

"Resilience and stability of ecological systems", Annual Review of Ecology and Systematics Vol 4, pages 1-23.

5. Wisner, Ben, Piers Blaikie, Terry Cannon and Ian Davis (2004), At Risk: Natural Hazards and People's Vulnerability, second edition, Routledge, New York, 447 pages.

6. IFRC (2010), World Disasters Report 2010: Focus on Urban Risk, International Federation of Red Cross and Red Crescent Societies, Geneva, 220 pages; also Pelling, Mark (2003), The Vulnerability of Cities: Natural Disasters and Social Resilience, Earthscan, Abingdon, 212 pages.

7. Cutter, S, L Barnes, M Berry, C Burton, E Evans, E Tate and J Webb (2008), "A place-based model for understanding community resilience to natural disasters", Global Environmental Change Vol 18, pages 598-606.

8. For summaries of these debates, see reference 7; also Klein, R, R Nicholls and $F$ Thomalla (2004), "Resilience to natural hazards: how useful is this concept?", EVA Working Paper No 9, DINAS-COAST Working Paper No 14, Potsdam Institute for Climate Impact Research, Germany, 7 pages. 


\section{See reference 7 .}

10. See reference 8, Klein et al. (2004), page 7.

11. Smit, B, O Pilifosova, I Burton, B Challenger, S Huq, R Klein and G Yohe (2001), "Adaptation to climate change in the context of sustainable development and equity", in J J McCarthy, O F Canziani, N A Leary, D J Dokken and $\mathrm{K} \mathrm{S}$ White (editors), Climate Change 2001: Impacts, Adaptation and Vulnerability, Contribution of Working Group II to the Third Assessment Report of the Intergovernmental Panel on Climate Change, Cambridge University Press, Cambridge, pages 877-912.

12. Da Silva, J, M Moench, $S$ Kernaghan, A Luque and S Tyler (2010), "The Urban Resilience Framework (URF)", ISET and ARUP, 4 pages.

13. Lewis, Dan (2013), "Urban resilience: from advocacy to implementation", Presentation to the UN-Habitat session at the UNISDR Global Platform for Disaster Risk Reduction, 22 May 2013, Geneva.

14. UNISDR (2012b), Making Cities Resilient Report 2012: A Snapshot of How Local Governments Reduce Disaster Risk, 116 pages, accessed 3 October 2013 at http:// www.unisdr.org/we/inform/ publications/28240. to risk-reducing interventions. Adaptive capacity is often included in definitions of resilience to encapsulate the importance of iterative approaches to resilience-building, which occurs through feedback cycles of planning, implementation and learning, and is informed by up-to-date risk knowledge. ${ }^{12)}$ This point has been emphasized by the burgeoning literature on climate change adaptation, where the lack of certainty on exactly how risks will change in each locality necessitates a flexible approach. The term "resilience" is often preferred to the term "adaptation" because it implies more capacity to protect against unanticipated risk or risk levels.

The UN Human Settlements Programme (UN-Habitat) and UNISDR promote resilience as a way to address key policy goals. Addressing resilience demands an integrated approach that starts with advocacy (such as the Making Cities Resilient Campaign), and includes policy (developing national and local frameworks), stimulating innovation (using advocacy/ policy to initiate new thinking) and final delivery - moving from thought to action (taking new approaches to urban planning, design and development). ${ }^{(13)}$

\section{METHODOLOGY AND SOURCES}

The findings presented here are based on the methodology adopted for a report prepared for the UNISDR in 2012.(14) This sought to draw out key themes of resilience-building from the documentation of more than 50 city governments involved in the campaign (Table 1). It used coding and thematic clustering of activities that city governments engaged in, which were then categorized according to the campaign's, "10 essentials

\begin{tabular}{|lll|}
\hline & \multicolumn{2}{c|}{ TA B LE 1 } \\
& Cities included in the analysis \\
\hline Albay, Philippines & Jakarta, Indonesia & Quezon City, \\
Amadora, & Johannesburg, South & Philippines \\
Portugal & Africa & Quirihue, Chile \\
Ancona, Italy & Kampala, Uganda & Quito, Ecuador \\
Bangkok, Thailand & Kathmandu, Nepal & Saijo, Japan \\
Baofeng, China & Kisumu, Kenya & San Francisco CA, \\
Batticaloa, Sri Lanka & Larreynaga-Malpaisillo, & USA \\
Beirut, Lebanon & Nicaragua & San Francisco, Cebu, \\
Bhubaneswar, India & Makassar, Indonesia & Philippines \\
Bonn, Germany & Makati, Philippines & Santa Fe, Argentina \\
Byblos, Lebanon & Mashhad, Iran & Santa Tecla, El \\
Cairns, Australia & Moshi, Tanzania & Salvador \\
Cape Town, & Mumbai, India & Siquirres, Costa Rica \\
South Africa & Narok, Kenya & Telica, Nicaragua \\
Chacao, Venezuela & Overstrand, & Thimphu, Bhutan \\
Colombo, Sri Lanka & South Africa & Tyrol Province, \\
Copenhagen, Denmark & Pakistan - 30 cities from & Austria \\
Ica region, Peru & Six regions & Valle de Itata, Chile \\
(Chincha, Pisco, & Pune, India & Vancouver (North), \\
Cañete and Ica) & Quezalguaque, & Canada \\
Istanbul, Turkey & Nicaragua & Venice, Italy \\
\hline
\end{tabular}


for making cities resilient", which draws on the principles of the UNISDR Hyogo Framework for Action (Table 2).

The documentation included presentations by local government representatives made at campaign meetings between 2010 and 2012, reports from the application of a Local Government Self-Assessment Tool (LG-SAT), and material prepared by local governments that applied for the UN-Sasakawa Award for Disaster Reduction. In addition, the authors conducted 11 interviews with campaign city representatives and received 10 written responses to a questionnaire. In total, documents and material from more than 50 cities and more than 90 sources were analyzed.(15) Apart from a few documents prepared by NGOs and researchers, the sources consisted of reports by local governments and responses by local government staff. The research provides a considerable level of detail as to the breadth of activities in
15. This included, in addition, a document that synthesized work from 30 cities in six administrative regions in Pakistan.

\section{TABLE 2}

\section{UNISDR's "10 essentials" for making cities resilient}

$1 \quad$ Institutional and administrative framework

$2 \quad$ Financing and resources

$3 \quad$ Multi-hazard risk assessment - know your risk

4 Infrastructure protection, upgrading and resilience

5 Protect vital facilities: education and health

6 Building regulations and land use planning

7 Training, education and public awareness

8 Environmental protection and strengthening of ecosystems

9 Effective preparedness, early warning and response

10 Recovery and rebuilding communities
Put in place organization and coordination to understand and reduce disaster risk based on participation of citizen groups and civil society; build local alliances; ensure that all departments understand their role in disaster risk reduction and preparedness

Assign a budget for disaster risk reduction and provide incentives for homeowners, low-income families, communities, businesses and the public sector to invest in reducing the risks they face

Maintain up-to-date data on hazards and vulnerabilities; prepare risk assessments and use these as the basis for urban development plans and decisions; ensure that this information and the plans for your city's resilience are readily available to the public and fully discussed with them

Invest in and maintain critical infrastructure that reduces risk, such as flood drainage, adjusted where needed to cope with climate change

Assess the safety of all schools and health facilities and upgrade these as necessary

Apply and enforce realistic, risk-compliant building regulations and land use planning principles; identify safe land for low-income citizens and develop upgrading of informal settlements, wherever feasible

Ensure that education programmes and training on disaster risk reduction are in place in schools and local communities

Protect ecosystems and natural buffers to mitigate floods, storm surges and other hazards to which your city may be vulnerable; adapt to climate change by building on good risk reduction practices

Install early warning systems and emergency management capacities in your city and hold regular public preparedness drills

After any disaster, ensure that the needs of the survivors are placed at the centre of reconstruction, with support for them and their community organizations to design and help implement responses, including rebuilding homes and livelihoods

SOURCE: UNISDR (2013b), "Toolkit for local governments - 10 essentials", accessed 9 December 2013 at http://www.unisdr.org/campaign/resilientcities/toolkit/essentials. 
16. The full range of activities is presented in detail in the report available at http:// www.unisdr.org/we/inform/ publications/28240.

17. The LG-SAT is undertaken by local governments and other local stakeholders who work together to assess the gaps and challenges that remain for disaster risk reduction. which local governments are engaged, but does not attempt to assess their impact on the ground.

\section{HOW ARE CITY GOVERNMENTS BUILDING RESILIENCE TO NATURAL HAZARDS?}

The analysis shows that local governments are involved in considerable and wide ranging DRR-related activities across the spectrum of the "10 essentials". The four types of activity occurring most frequently are: considering DRR in new urban planning regulations, plans and development activities; setting up councils/committees/disaster management structures dedicated to DRR; constructing or enhancing hazard-mitigating infrastructures; and setting up education/awareness/ training programmes.

The following section presents a selection of these activities, and specifically those related to certain of the essentials presented in Table 2, namely: the institutional and administrative framework; financing and resources; multi-hazard risk assessments; infrastructure protection, upgrading and resilience; and building regulations and land use planning. (16) Each of these is presented using a table of indicators, largely based on indicators developed for the Local Government Self-Assessment Tool (LG-SAT) of the campaign. ${ }^{(17)}$

\section{a. The institutional and administrative framework: governance for disaster risk reduction (DRR)}

The campaign and the Hyogo Framework for Action note the need to have an institutional basis for implementing risk reduction and to involve all sectors and stakeholders. As Table 3 indicates, some campaign cities have created municipal level institutions to address disaster risk and climate change. Rather than creating a new sector, these largely play a coordinating role, bringing together the various functions and expertise of existing government departments to focus on hazard risks. In some countries, national frameworks and laws have helped create these municipal level institutions. Cities are also engaging with a wide range of stakeholders beyond government departments, including multi-lateral and bi-lateral organizations offering technical support, universities and research organizations, the private sector, and NGOs and other civil society groups.

City and local level institutional structures. In some cities, attention to DRR has entailed expanding the mandate of existing bodies beyond emergency preparedness and response to include addressing disaster risk, climate change and resilience. For example, in Bhubaneswar, India, the city government has expanded the focus from post-disaster response towards disaster risk management, setting up institutions at the city and ward levels to address this. Many of the examples of cross-sectoral collaboration are related to specific disaster risks and the collaboration needed in emergency situations. In Colombo, Sri Lanka, the Ministry of Defence has set up a task force consisting of all organizations with responsibility for flood mitigation. 
TABLE 3

\section{Cities reporting that they have taken actions to improve governance for disaster risk reduction (DRR)(1)}

Indicators

Cities reporting that they have local organizations equipped with capacities (knowledge, experience, official mandate) for DRR and climate change adaptation

Cities reporting that they have partnerships between multiple stakeholders, including communities, the private sector, NGOs, research institutions, bilateral agencies and/or local authorities, for risk reduction-related activities
Cities reporting that the local government supports vulnerable groups (particularly women, the elderly, the infirm, children) to actively participate in risk reduction decision-making, policy-making, planning and implementation
Cities

Makassar: Disaster Management Agency (BNPB) set up to oversee DRR efforts and coordinate between government departments

Bhubaneswar: set up DRR institutions at city and ward level

Albay: central coordinating office for disaster preparedness, response and recovery

Makati and Quezon City: city level Disaster Risk Management Council has barangay level operating arms

Dubai: created Crisis and Disaster Management team with representation from all major utilities and agencies

Barcelona: Barcelona Resilience Board - a network of 37 institutions, including many part-private utility companies and regional government

San Francisco (Philippines): purok structure for disaster risk management (level below barangays) allows for participatory risk governance Colombo: task force for all actors involved in flood mitigation Pune: flood risk reduction managed jointly by municipal government departments and citizen groups

Cape Town: school awareness programmes in partnership with arts NGO; multi-stakeholder input to DRR plans

Johannesburg: multi-stakeholder dialogue for DRR plans

Overstrand: partnership between government, NGOs and communities in Working for Water programme

Albay: consultation of scientific experts in risk planning

Kisumu, Mumbai, Istanbul, Makati, Dubai: technical support for developing DRR activities

Makassar: NGOs involved in community development projects; school preparedness programme in partnership with Indonesian Red Cross Makati: NGO partnership for squatter relocation programme; partnership with Philippine Institute of Volcanology and Seismology and Kyoto University, Japan; first-response training delivered in partnership with Philippine Red Cross

Kisumu: NGO partnership provided funding for DRR

Batticaloa: NGO partnership supporting development activities; partnership with University of Salford (UK)

Cape Town, Makassar, Makati: Corporate Social Responsibility used for DRR and disaster recovery

Chacao: 33 companies in risk management network

Tyrol: partnership with Alps Centre for Climate Change Adaptation

Technologies to facilitate disaster risk management planning

Santa Tecla: citizen round tables fed into 10-year development plan

Makati: citizen participation in city planning

Thimphu: public consultations for 25-year structure plan

Albay: community contributes to local risk-mapping; community-based early warning system

Tyrol: risk assessment combined expert and community knowledge

North Vancouver: local volunteer task forces identify "risk tolerance criteria" used in city DRR activity prioritization

Bhubaneswar: volunteer residents trained in emergency response San Francisco (Philippines): Neighbourhood Empowerment Network conducts community consultations

Quezon City: Walk the Fault participatory risk-mapping 
Indicators

Cities reporting that the local government participates in national DRR planning

Cities reporting that national level DRR frameworks are enabling city level DRR institutions
Cities

Albay: climate change adaptation practices at provincial level fed into national policy design

All cities in the Philippines: National Disaster Risk Reduction and Management Act (2010)

Makassar: National Act No 24 (2007) on Disaster Management Cape Town and Johannesburg: 2002 Disaster Management Act

NOTE: (1)In this and other Tables, the nations where cities are located are not included as they are listed in Table 1.

Cities have reported that the institutionalization of DRR and disaster management is most effective where specific people or departments within local government are made legally responsible for implementation and coordination among all relevant departments or sectors. In Albay, Philippines, redefining the functional roles and responsibilities of the members and task units has been one of the key practices for enabling better risk reduction.

Beyond having a coordinating structure at the city scale, cities in the Philippines have institutionalized a more local community-scale structure for disaster risk management. For example, in San Francisco, they have instituted structures for disaster management at the purok level, which is one level below the barangays, and the lowest level of governance.

In some countries, the development of city level institutional structures has been enabled by national legislation on DRR. This points to the importance of national level legislation as a mechanism for framing responsibilities of local governments, providing them with the capacity to manage disaster risk and, in some cases, a funding structure to help establish local government institutions. In the Philippines, the National Disaster Risk Reduction and Management Act of 2010 provides clearly defined roles for cities and municipal governments, noting that local disaster risk reduction and management offices should be under the office of the governor, the city or the municipal mayor, and specifies duties and number of staff.

Some cities are part of regional partnerships that bring together municipalities or provincial authorities to address disaster risks related to a geographic region, for example flooding along a river system or inundation on a coast. Quezon City, Philippines, is part of the alliance of seven cities/municipalities that are working together to reduce the impact of flooding in the region. In Indonesia, similarly, the Jakarta regional government has helped to form a coordinating board for the rivers and watercourses in the region.

Engaging multiple stakeholders in risk reduction. Cities are also engaging with a wide range of stakeholders beyond government departments, including multi-lateral and bi-lateral organizations offering technical support, universities and research organizations, the private sector, and NGOs and other civil society groups. In Albay, local government 
has been instrumental in establishing the Centre for Initiatives on Research and Climate Action in collaboration with several other organizations, including the Environmental Management Bureau, World Agroforestry Centre, Bicol University, University of the Philippines Los Banos and the provincial government's Albay in Action on Climate Change programme. In Kisumu, Kenya, it was reported that the only direct funding for DRR came from NGOs, as the municipality did not have a budget committed to DRR programmes and activities. In an effort to increase the scope of DRR activities, some municipalities are seeking to engage the private sector in risk reduction activities. In Siquirres, Costa Rica, the private sector donated materials for infrastructure improvements; and in Cape Town, South Africa, a private company volunteered its resources for the hazard assessment.

Municipalities are also placing emphasis on the role of communities and households as partners in risk reduction. Communities are involved in different types of activities: participating in decision-making with municipalities through planning and policy-making; generatinginformation about risk and communicating risk; and taking direct responsibility for DRR activities, a form of co-production that reduces the burden on municipal governments. In Santa Tecla, El Salvador, citizen round tables are brought together to participate in periodic discussion and decision-making about the future of the city. Following two devastating earthquakes in 2001, the city is developing forward-thinking plans for urban development (up to 2020), and the involvement of citizen groups is key.

Municipalities are also engaging with communities to enhance information about risk (Table 4). Community involvement extends the capacity of municipalities to gather risk information and allows a better understanding of people's perceptions of risk. In Albay and Makati, Philippines, communities are taking part in risk-mapping and communicating these findings to the municipalities. In North Vancouver, Canada, residents are developing "risk tolerance criteria" (communities' tolerable level of risk) for landslides and forest fires. A natural hazards task force made up of eight volunteer district residents listened to subject matter experts, consulted the public for their input and then made recommendations to the city council for the city's current policy for risk tolerance, which directs what risk reduction activities the city should engage in.

Some municipalities are encouraging communities to share responsibilities for risk reduction. In Moshi, Tanzania, to reduce the burden on the municipality for flood preparations, communities are encouraged to take responsibility for drains in front of their houses on a weekly basis. In Bhubaneswar, the municipality has trained residents as volunteers in search and rescue, first aid, relief management, water and sanitation provision, damage assessment and debris management.

\section{b. Financing and resources for risk reduction}

While there are innovative methods for financing in many of the cities, most report that funding for risk reduction is still lacking, especially in cities at the early stages of resilience-building such as Kampala, Uganda, and Kisumu, Tanzania. Funds for disaster response, either at national or local level, are more common than funds for DRR. Cities such as Ancona, 
TABLE 4

Local governments undertaking multi-hazard risk assessments

Indicators about multi- Cities

hazard risk assessments

Cities reporting that local government conducts thorough disaster risk assessments for key vulnerable development sectors

Cities reporting that they draw on communities' knowledge in their hazard risk assessments

Albay: mapping of typhoons, earthquakes, volcanic hazards, tsunamis, floods, landslides and mudflows (lahar), vulnerable populations and existing land uses; mapping exercises carried out by different partners, including the Mines and Geo-Sciences Bureau, Manila Observatory; some of these done in-house by the local government

Makati: Climate and Disaster Resilience Initiative helping to gather baseline information on the city's resilience; risk-profiling for earthquakes, floods, liquefaction and landslides carried out with different partners

Cape Town, Johannesburg: a comprehensive disaster risk assessment is part of statutory legislation; includes multiple hazard analysis and community-based risk assessment

Quito: municipal government has conducted several vulnerability and risk assessments but has identified that this needs to be done more regularly to reflect constantly changing conditions

Pune: municipality prepared flood risk maps by analyzing hourly rainfall intensity and examining the likely impacts in low-lying areas and places where natural drainage was blocked by the construction of houses or roads without adequate bridges; also created a detailed map of the city's drainage

Bhubaneswar: community risk assessment institutionalized at the ward level, including training of volunteers from NGOs on mapping exercises

Quezon City: the Walk the Fault project is a collaboration between local leaders and community members and identifies the course of the earthquake fault line that passes through the city

North Vancouver: resident volunteers developed criteria on the communities' tolerable level of risk for landslides and other hazards

Narok, Kisumu, Moshi: communities use informal and local/indigenous knowledge of hazard risks, weather patterns and response activities

How the local government Makati: monthly publication of printed materials, weekly radio programme communicates local hazard trends featuring discussion about disaster risk management

Cape Town: dissemination of printed materials

Saijo: distribution of hazard booklets in public spaces

Makati: dedicated DRR radio programme

Makassar: disaster risk management website

Cities reporting that Johannesburg: vulnerability and risk assessment feeds into disaster and disaster risk assessments are incorporated into local development planning

adaptation planning, including the Comprehensive Disaster Management Plan Cape Town: comprehensive disaster risk assessment feeds into strategic planning process

San Francisco (Philippines): the 2008 assessment on hazards, vulnerability and capacities and climate risk conducted by the municipality became the basis of priorities and projects implemented in the municipality

Pune: flood risk maps used to prioritize structural and planning measures, for example stream-widening and bridge extensions

Italy, emphasize the need to expand funding for risk reduction at the city level but further emphasize that national level policies are needed to encourage this.

In looking at municipal budgets for resilience initiatives, there appear to be two main routes (Table 5). The first is having a distinct budget for DRR and recovery channelled through a disaster management agency. 


\title{
TABLE 5
}

\section{Types of financing and resources local governments draw on for disaster risk reduction} (DRR) activities

\author{
Type of financing \\ City examples
}

Budgets for DRR directly allocated by municipality or other government body

Budget for DRR mainstreamed into other city budgets or development projects

National budget for DRR available to local governments

Budget for disaster relief/ response/recovery available if needed (including microcredit to households)

Measures to support vulnerable households in pre-disaster times

Economic incentives for households and businesses investing in DRR
Barcelona: funds for Resilience Board activities come from local government

Beirut: special budget for DRR allocated by municipal government Cairns: annual operating budget provided for its Disaster Management Unit, coordination centre, volunteer emergency services and community awareness programmes

Makassar: specific budget allocation for DRR activities such as improved disaster-mapping, training on risk mitigation, emergency response unit and relief supplies

Colombo: specific budget allocation from national level for flood control and town planning, both related to DRR; also municipal council disaster fund for relief services

All cities in the Philippines: national legislation mandates provincial budget for DRR

Quito: all municipal departments allocate some budget to DRR through existing projects and programmes

Cape Town: financial support for risk reduction projects comes from existing development or environmental projects

Makassar: budgets for DRR mainstreamed through municipal development projects such as upgrading of informal settlements and improving the water supply, which aim to reduce the impacts of flooding and fires

Philippines: National Disaster Risk Reduction and Management Act (2010) dictates that local government must allocate $>5 \%$ of total revenue to DRR, $30 \%$ of which may be spent on response and $70 \%$ on preparedness; local governments may also use $20 \%$ of the internal revenue allotment from national government

Thimphu: King awards grants to worst-affected families to relieve personal loss following a disaster

Makati: some people have access to loans in disaster situations - Makati City Employees Cooperative provides emergency loans for calamity, hospitalization, death of family members, among others

South Africa: national level funds available if disaster is declared

San Francisco (Philippines): purok "capital build-up" programme acts as a community resource/capital pool for DRR and emergency capital Makati: universal health insurance coverage for Makati constituents San Francisco (Philippines): financial incentives for effective community (purok) resilience-building activities

For example, in Beirut, Lebanon, one of the first activities after signing onto the campaign in October 2010 was to allocate a special budget for DRR. The second route is mainstreaming DRR through existing municipal department budgets, facilitating risk reduction through existing municipal projects and programmes. In Quito, Ecuador, each entity within the municipality allocates some of its budget for risk reduction. Many cities effectively have a two-tier system for funding DRR, with direct budgets for DRR and also DRR mainstreamed into municipal projects and programmes. 
18. UNISDR (2009), Global Assessment Report on Disaster Risk Reduction: Risk and Poverty in a Changing Climate, Geneva, 207 pages; also UNISDR (2011a), Revealing Risk, Redefining Development: The 2011 Global Assessment Report on Disaster Risk Reduction, Geneva, 178 pages; and UNISDR (2013a), From Shared Risk to Shared Value; the Business Case for Disaster Risk Reduction. Global Assessment Report on Disaster Risk Reduction 2013, Geneva, 246 pages and annexes. The full texts of these documents and background papers prepared for them are available at http:// www.unisdr.org/we/inform/gar.

19. This section includes actions related to Essential 4: Infrastructure protection, upgrading and resilience, and Essential 6: Building regulations and land use planning.

\section{c. Multi-hazard risk assessments}

Many cities report on the inadequacy of data on hazards, vulnerabilities and risks and how this holds back their ability to implement risk reduction. The three UNISDR Global Assessment Reports highlight that detailed local records of disasters both increase and change the government's understanding of hazard and risk - but also provide a much stronger base for DRR. ${ }^{(18)}$

As Table 4 indicates, many of the campaign cities have undertaken some kind of hazard and vulnerability assessment and have created hazard risk maps, often using GIS systems. These also feed into policy. For example in Cape Town, the local government's citywide Comprehensive Disaster Risk Assessment includes an assessment of scientific hazard and vulnerability analysis as well as community-based risk assessments to ensure that development initiatives and disaster planning are informed by accurate, locally based knowledge. This has led to a 15 per cent increase in anticipated rainfall intensities, an estimation that has been used in planning stormwater systems and flood management. Other policy responses include the identification of a coastal protection zone and a climate adaptation plan of action that includes catchment management plans, infrastructure investment strategy and building plan approval for the city.

\section{d. Upgrading informal settlements, infrastructure and urban planning ${ }^{(19)}$}

It is common in cities in low- and middle-income nations for 20 to 70 per cent of their population to live in informal settlements. The major challenges for resilience lie in developing the necessary basic infrastructure for water, sanitation and drainage, improving roads and supporting housing improvements. Some of the cities are addressing these issues though upgrading projects and programmes (Table 6). In addition to improving health and residents' quality of life, upgrading makes lowincome settlements and cities more resilient to a range of natural hazards, including flooding and fires.

Local governments are addressing flood risk through infrastructure and engineering projects. Some are large-scale, multi-sector investments such as the investment in stormwater drainage in Mumbai, India (Table 6). Others are small scale, such as in Siquirres, a town of 59,000 people, where the municipality has built concrete reinforcements for creek embankments and increased underground water piping by the roadside to avoid spillover into the road and to prevent flooding of nearby houses. This has greatly reduced the impact of annual flooding and was completed with a small budget using resources from the private sector and communities.

Integrating a detailed understanding of disaster risk into urban plans and land use management requires good coordination between different sectors, as well as detailed local data on risks and a commitment to DRR. Some campaign cities have made progress on some of these - especially in integrating a concern for DRR into city plans and land use management. In Bhubaneswar, after an initial risk assessment in 2003, the city updated its master plan and revisited its building by-laws to account for hazard risks. In Makassar, Indonesia, prompted by the devastating landslides in 2004, hazard risk and vulnerability are now included in its land use 


\section{TABLE 6}

\section{Local governments that take into consideration hazard risks in planning, infrastructure investments and informal settlement upgrading}

Indicators on

Cities

urban planning and

infrastructure upgrading

Cities that have

implemented upgrading of informal settlements in part to address hazard risks

Cities reporting that they have implemented engineering or infrastructure solutions to address hazard risks

Cities that have urban plans or land use policies that address hazard risks

Cities with building codes or standards that address hazard risks
Makassar: upgrading in 42 urban slums

Cape Town: in-situ upgrading of houses and infrastructure in four informal settlements to ensure access for emergency vehicles, water and sanitation, electricity

Kisumu: pilot upgrading programme in flood-prone communities, supported by the National Kenya Slum Upgrading programme; funds from Constituency Development Funds and Local Area Transfer Implementing Funds used to build large drain in Nyalendo settlement

Moshi: city council and national government to undertake a small informal settlement upgrading programme to improve roads and drainage systems and provide waste management

Mumbai: investment in stormwater drainage system designed to cope with 50 millimetre/hour rainfall - widening and deepening of existing water channels, rehabilitation of old drains, providing smooth transition for waterways near bridges, upgrading pumping system, annual de-silting of the system, cyclone shelters

Albay, Makati, Colombo, Bangkok, Cairns, Thimpu and Kisumu: undertaking major infrastructure improvements for improved drainage and control of floodwaters

Siquirres: concrete embankments and drainpipe enlargements Moshi: installation of fire hydrants around the city to reduce fires in the settlement

Bhubaneswar: updated master plan and building by-laws to respond to 2003 risk assessment

Quito: developing risk-sensitive land use plan

Cairns: urban plan has specific guidance to regulate development in areas prone to landslides, bushfires and flooding; this is linked to the regional Disaster Management Plan

Makassar: hazard, risk and vulnerability are included in land use plans for Makassar (2005-2015); projects must undergo an environmental impact assessment

Makati: risk-sensitive urban redevelopment planning project; environmental compliance of new and existing developments is required before granting clearance; projects in hazard-prone areas may be required to submit additional studies

Albay: province supported training of 18 municipalities in preparing comprehensive land use plans that address climate and disaster risks

Cape Town: by-law in place to enforce coastal protection zone Thimpu: considering how to better address earthquake and flood risks with existing plan

Colombo: efforts to minimize unplanned urban development, prevent unauthorized construction, discourage investments in environmentally sensitive and risk-prone areas

Makati: annual inspections to ensure National Building Code compliance Bhubaneswar: enforcement through training building professionals on rapid visual screening 
Indicators on

urban planning and

infrastructure upgrading
Cities engaged in relocation or eviction from disaster-prone areas
Cities

Makassar: building permits issued for every building and development based on project assessment according to various criteria, including environmental impact Thimpu: strict design requirements for earthquake risk; development control and limits on density and land coverage for landslide risk and wind load standards for cyclone risk

Quito: Greater Control Agency; review regulatory compliance for land use, construction and other building activities

Mumbai: 2,652 residential and 1,148 commercial structures removed

San Francisco (Philippines): removal and relocation of communities and

structures in areas prone to storm surge

Makati City: relocation of informal settlements along waterways and in landslide-prone areas

Albay: relocation of businesses and 10,076 households in Guicadale for new airport and road networks

Quito: resettlement from high-risk area if city is unable to undertake risk reduction measures

Colombo: removal of unauthorized structures on drains and encroachments into the canals

Kampala: eviction and resettlement of people encroaching on wetland areas

plans (2005-2015). All projects that may affect the natural environment, including natural hazards, are required to undergo an environmental impact assessment and must be granted an environmental compliance certificate before they can go ahead.

Local governments report that they have building codes that take into account hazard risks, and methods for implementing codes and building standards (Table 6). But most report difficulties in achieving compliance with the codes, either because of a lack of staff or weak legislation. Thimphu, Bhutan, has outlined in some detail the problems it is having with compliance with building codes. People complain about the increased costs of construction due to the structural requirements for seismic risks and also about the regulation that allows only 20 per cent of a plot to be built on in order to keep down flood risks. Without incentives, they report that this rule is at risk of being amended. Bhubaneswar has taken a different approach to helping with compliance with seismic building codes. They have trained engineers, architects and planners on rapid visual screening, a technique to identify the earthquake-resistant capacity of the built environment, and have also provided training on earthquake engineering, multi-disaster construction technology and earthquake-resistant construction technology.

Local governments in Mumbai, Makati, Albay, San Francisco (Philippines), Quito, Colombo and Kampala report their involvement in relocation programmes to move people living in low-lying or steep slope informal settlements to safer sites (Table 6). A growing number of cities are engaging in relocation programmes justified by DRR. But much more needs to be done to understand when this is needed and how it should be implemented. While in some situations the relocation of some informal settlements along waterways may have the desired impact of relieving flooding, it often has serious socioeconomic impacts on the relocated 
TABLE 7

The most important milestones for building resilience according to mayors and city managers (based on the "10 essentials" listed in Table 2)

\begin{tabular}{|c|c|c|}
\hline Essential & Indicator & City \\
\hline 1 & Interest from local authorities, regional government and community leaders & Valle de Itata \\
\hline 1 & $\begin{array}{l}\text { A unique division called Disaster Management in Municipality as the main } \\
\text { responsible authority in the city }\end{array}$ & Mashhad \\
\hline 1 & $\begin{array}{l}\text { Full coordination among municipalities and other institutions related to disaster } \\
\text { management }\end{array}$ & Mashhad \\
\hline 1 & $\begin{array}{l}\text { Level of stakeholder buy-in, e.g. membership of committees, participation of } \\
\text { different sectors in resilience-building activities }\end{array}$ & Siquirres \\
\hline 1 & $\begin{array}{l}\text { Community engagement (e.g. being grateful for projects, receiving comments } \\
\text { and suggestions) }\end{array}$ & Siquirres \\
\hline 1 & Mayor signing onto the campaign as commitment to DRR & Ancona \\
\hline 1 & Policies put in place by the governor & Bangkok \\
\hline 1 & Municipalities working together in DRR & Valle de Itata \\
\hline 1 & Creation of dedicated boards for DRR & Barcelona \\
\hline 1 & Allowing youth to step up and take ownership & Cape Town \\
\hline 1 & Political will and long-term vision from authorities & Telica \\
\hline 1 & Coordination and cooperation among various stakeholders & Amadora \\
\hline 2 & Securing national level budget for local level DRR & Siquirres \\
\hline 3 & Risk assessment studies undertaken & Amadora \\
\hline 3 & Internal/self-assessment of hazard risk and internal capacities to build resilience & Siquirres \\
\hline 4 & Construction of 100 septic tanks for 100 houses & Telica \\
\hline 4 & Number of completed infrastructure improvements to cope with floodwaters & Siquirres \\
\hline 5 & Special work to make schools safer & Telica \\
\hline 6 & Reconstruction and retrofitting of high-risk urban areas & Mashad \\
\hline 6 & Prioritizing high-risk communities (informal settlements) & Cape Town \\
\hline 7 & Publications about good practices & Amadora \\
\hline 7 & International recognition and awards (e.g. being a role model, Sasakawa Award) & $\begin{array}{l}\text { San Francisco } \\
\text { (Philippines) }\end{array}$ \\
\hline 7 & $\begin{array}{l}\text { Becoming part of international networks, which facilitates knowledge-sharing } \\
\text { and increases competition between cities, which motivates them to do more }\end{array}$ & $\begin{array}{l}\text { San Francisco } \\
\text { (Philippines) }\end{array}$ \\
\hline 9 & Installation of flood-warning systems & Mashad \\
\hline 9 & $\begin{array}{l}\text { Nationwide earthquake drill held in Mashhad at the highest level and in most } \\
\text { crowded areas }\end{array}$ & Mashad \\
\hline All & The number of initiatives that have been achieved & Amadora \\
\hline
\end{tabular}

communities. ${ }^{20)}$ Relocation programmes often impoverish those who have moved, and they face disruption to their livelihoods and social networks. This may cancel out any benefits of moving to a safer location, unless it is planned, managed and costed with genuine consensus of the residents affected.

\section{WHAT DO LOCAL GOVERNMENTS SEE AS THE KEY MILESTONES FOR BUILDING RESILIENCE IN THEIR CITY?}

In the interviews with mayors and city managers, we asked what they saw as the important milestones for building resilience in their cities. The
20. Oliver-Smith, Anthony (2011), Defying Displacement: Grassroots Resistance and the Critique of Development, University of Texas Press, Austin, 316 pages. 
objective was to understand what local governments view as the building blocks of resilience and how this compares across the cities. The results are reported in Table 7, which shows a heavy concentration of responses on the first essential, namely the institutional and administrative framework. It is to be expected that mayors and city managers see governance as a key ingredient for resilience, yet the responses are also quite diverse with regard to the relevant aspect of governance. In some, it is the development of a dedicated body, or political commitment, in others it is that different sectors and actors work together.

The second aspect that features strongly is the completion of projects to address specific risks in that city; this may be the enhancement of flood infrastructure, retrofitting of buildings or the construction of safe schools. Each city sees different aspects as important for resilience, and these are context specific. A city with a large stock of buildings that are not earthquake resilient would see retrofitting and replacement of building stock as an important milestone. A city that has recently had a large-scale disaster would see risk-sensitive urban planning and its implementation as a key milestone.

\section{WHAT HAS BEEN THE VALUE-ADDED OF THE CAMPAIGN FOR ENABLING LOCAL GOVERNMENTS TO TAKE ACTION?}

Getting political momentum behind risk reduction is seen as a factor that can enable local government action, particularly where substantial changes to the status quo are necessary to improve disaster resilience. Political will is important to resist the momentum of existing practices and to drive the introduction of new and progressive risk reduction policies. The strength of a global advocacy campaign such as the Making Cities Resilient Campaign is that is legitimizes the actions of local governments on DRR, giving exposure and validation to existing local government activities. For local governments in the early stages of resilience-building, it helps to motivate and galvanize political actions. Yelgi Verley, the mayor of Siquirres stated that:

"Without the campaign we would not have been this fast. If I didn't register in this campaign I'm not sure if we would have reached out to do these things we are doing now. To have started my own administration with this campaign has caused a complete change in what my focus is as mayor."

21. UNISDR (2011b), Taking Stock of Progress and Future Strategy on the Resilient Cities Campaign: Summary of Responses from Partners, Report on feedback from ICLEI, EMI, UN-Habitat, Asia RTF-URR, ADPC, WCSDA, RMIT, GROOTS International, provided by UNISDR, May 2012, 7 pages.
A survey of campaign partners in 2011 outlined the ways in which the campaign's advocacy work has enabled DRR:(21)

- giving city authorities greater visibility for work already being done on disaster risk management and DRR;

- providing a framework for dialogue between stakeholders from different disciplines that supports cities as they conduct disaster risk self-assessments;

- creating a ready-made platform for city-to-city exchange at an international level; 


\section{TABLE 8}

Declarations of commitments to DRR action signed by mayors

\begin{tabular}{|c|c|c|c|}
\hline Declaration & Date & Signatories & Commitments \\
\hline $\begin{array}{l}\text { Mayors Statement } \\
\text { on Resilient Cities }\end{array}$ & 13 May 2011 & $\begin{array}{l}20 \text { mayors and } 8 \\
\text { local government } \\
\text { representatives }\end{array}$ & $\begin{array}{l}\text { Work towards DRR; raise awareness about } \\
\text { the issue; work together to make change }\end{array}$ \\
\hline $\begin{array}{l}\text { Bonn Declaration } \\
\text { of Mayors }\end{array}$ & 5 June 2011 & $\begin{array}{l}\text { Mayors from } 35 \\
\text { cities in } 30 \text { countries }\end{array}$ & $\begin{array}{l}\text { Commitment to globally coordinated action } \\
\text { on climate change; outlines action points } \\
\text { related to adaptation and resilience and } \\
\text { calls for all cities to sign up to the campaign } \\
\text { to further collaborative actions, learning } \\
\text { cooperation and networking }\end{array}$ \\
\hline $\begin{array}{l}\text { Chengdu } \\
\text { Declaration }\end{array}$ & 13 August 2011 & $\begin{array}{l}39 \text { local government } \\
\text { representatives from } \\
18 \text { countries and } \\
\text { many international } \\
\text { organizations }\end{array}$ & $\begin{array}{l}\text { Includes actions on enabling cooperation } \\
\text { between cities, incorporating disaster- } \\
\text { resilient initiatives into urban development } \\
\text { planning and raising awareness in cities } \\
\text { about risk reduction }\end{array}$ \\
\hline $\begin{array}{l}\text { European Council } \\
\text { Resolution } 339 \\
\text { - Making Cities } \\
\text { Resilient }\end{array}$ & 22 March 2012 & $\begin{array}{l}\text { Adopted by the } \\
\text { Council of Europe }\end{array}$ & $\begin{array}{l}\text { Calls on all local and regional authorities in } \\
\text { Council of Europe member states to sign } \\
\text { up to the Making Cities Resilient Campaign } \\
\text { and encourages them to undertake an } \\
\text { integrated approach to DRR and climate } \\
\text { change adaptation; promotes the sharing } \\
\text { of best practices and the development } \\
\text { of partnerships, lobbying for increased } \\
\text { awareness and drawing up and implementing } \\
\text { strategic programmes and action plans }\end{array}$ \\
\hline
\end{tabular}

- enabling cities to receive recognition from UNISDR through the Role Model City framework, the UN-Sasakawa Award for Disaster Risk Reduction and other frameworks associated with the campaign; and

- drawing media attention to DRR, which in turn triggers greater accountability among local government authorities as well as citizens.

Engaging in partnerships or learning exchanges with other cities has been instrumental in building momentum for DRR activities. The campaign organizes regular city-to-city learning events, which have helped cities to share practices and look at ways to further enhance resilience activities. The mayor of Ancona said that the campaign has been instrumental in helping to build partnerships and networks and to engage with international networks of other cities. A significant achievement of the campaign in fostering political will has been the elaboration of several mayoral/local government declarations committing to city level actions on resilience. Four declarations, which have included more than 100 mayors and local government representatives, have been signed since May 2011 (Table 8). ${ }^{(22)}$

The Local Government Self-Assessment Tool (LG-SAT) presents a tangible framework for highlighting resilience-building activities, and catalyzes action by bringing together people from across different departments of local governments to examine how DRR is being
22. There are other important local government declarations, for example the Durban Adaptation Charter, which commits local governments to climate action. 


\section{TABLE 9}

Cities taking part in the pilot phase of the Local Government Self-Assessment Tool (LG-SAT) and the benefits reported from this exercise

Cities taking part in the pilot phase of the LG-SAT

Johannesburg

Makati

Pakistan - 30 cities from 6 administrative regions

Narok, Kisumu, Moshi

Makassar

Cities across many local governments in the Philippines Santa Fe
Benefits of the LG-SAT process identified by local governments

Brought actors together in multi-stakeholder consultations: community councillors and leaders, staff from different departments, businesses, NGOs, research institutions Multi-stakeholder dialogue approach in LG-SAT encouraged discussions on new DRR projects

LG-SAT has revealed weaknesses and helped stakeholders to identify priority areas for action; multi-stakeholder meetings in cities around doing the LG-SAT have been useful in identifying challenges to overcome and capacities to be enhanced The consultation process for the application of LG-SAT provided a concrete opportunity to discuss DRR; as a result of taking part in the assessment, city knowledge and networks have expanded and stimulated further interest and demand for information LG-SAT identified the low capacity of the local authority; the Makassar government has committed to integrating LG-SAT into the Disaster Management Agency's strategic programmes for 2011-2014 and the results will be used in plans for land use and economic development 2011-2031

The use of LG-SAT has been welcomed to raise awareness at national level of local capacities

The LG-SAT process is enhancing dialogue between local and national government and could be a useful tool for monitoring progress in the future

undertaken in their jurisdiction. When undertaken in the campaign cities, it has helped to spur discussions about DRR, stimulated interest and a demand for further information about risk, helped to diagnose current weaknesses and embedded DRR in broader urban activities (Table 9). The LG-SAT, particularly, has offered the opportunity for departments to work more closely together and to mainstream the issues across departments. Charlotte Powell, Director of Public Awareness and Preparedness in the Disaster Risk Management Centre, Cape Town, stated that:

“... there's now an understanding of how we need to integrate with each other. The LG-SAT has given us the opportunity for people to understand the role of disaster risk management and how they can make a change in doing bottom-line risk reduction."

The campaign also acts as a catalyst for facilitating technical assistance for DRR from other specialist institutions such as the Earthquake and Mega-cities Initiative, Asian Disaster Preparedness Centre and ICLEI Local Governments for Sustainability. For example in Quirihue, Chile, getting involved in the campaign made training to build DRR capacities available from UN-Habitat, Territoires Solidaires and UNISDR. In Batticaloa, Sri 
Lanka, the city wants to participate in the campaign so that they can get access to expertise, partners and learning opportunities, and to provide a platform to attract external funding for risk reduction, as well as to raise awareness of its officials.

\section{WHAT DOES THIS MEAN FOR OUR UNDERSTANDING OF RESILIENCE?}

The activities of local governments show the wide range of responses to risk at city level. They are much influenced by each local context, including the size of the city and its stage of development. Many attempts are being made to measure and quantify resilience in order to benchmark progress for policy-making and investment. ${ }^{(23)}$ Given that resilience has now firmly hit the policy arena, and the concept is being applied in practice, there is a need for a definition of resilience that is tangible, meaningful and operational, informed by academic reasoning and practical experience, and premised on principles of equity and human well-being.

The observations and priorities of city governments can be drawn on to refresh and progress our understanding of resilience. These reflect how resilience-building is played out in real, on-the-ground urban contexts, revealing much about the concept's meaningfulness to decision makers and citizens in practice. This tells us much about what resilience "really" means and how it may be actively pursued. Three key learning points are identified below.

\section{a. Early stages of resilience-building versus advanced resil- ience-building}

Among the earliest responses observed in cities is the creation of new DRR committees or working groups, which create a dedicated space to discuss risk issues. An example is in Rwanda, where UN-Habitat assisted the central government in rolling out a national programme institutionalizing disaster risk committees in self-selecting urban municipalities. Other activities taking place among cities at early stages of resilience-building include:

- undertaking risk assessments (Table 4);

- applying simple structural solutions to reduce hazard impacts (Siquirres);

- environmental protection measures such as tree-planting or wetland conservation (Kampala); and

- writing DRR into city development plans (Thimphu).

Cities at a more advanced stage of resilience-building (such as those in South Africa, the Philippines, India and Italy) are characterized by more advanced governing and technical capacities to address multiple risks, for example:

- national and city level DRR institutions;

- centralized coordinating mechanisms to act as a liaison point between relevant actors in case of emergency; and

- education programmes to ensure that the public and organizations have a high awareness of DRR issues and their respective roles.
23. For example the UNHabitat City Resilience Profiling Programme. 
24. Satterthwaite, David (2013), "The political underpinnings of cities' accumulated resilience to climate change", Environment and Urbanization Vol 25, No 2, pages 381-391.
To establish effective institutions that understand and can respond to known sources of risk in the city, it is necessary to build and maintain a body of technical knowledge and expertise. Cities with more advanced resilience-building activities also tend to have databases and hazard risk maps that policy makers are using to inform decisions about planning and city development (observed in Johannesburg and Cape Town). Other activities that are characteristic of later stages of resilience-building are institutionalization of community participation (such as in North Vancouver) and fostering multi-sector, cross-scale and international partnerships (for example in Albay).

\section{b. A resilient city requires DRR and accumulated resilience}

Urban resilience can come from two sources or pathways. The first is the set of activities undertaken to directly reduce exposure and sensitivity to known hazards. Together, these activities come under the umbrella of DRR and include hazard mitigation infrastructures, risk assessment and hazard-mapping, risk awareness and education, risk-sensitive urban planning, preparedness and emergency response activities. But urban resilience is also related to additional qualities not associated with direct DRR activities. These are the product of accumulated resilience, which is the "built-in" resilience a city has accumulated through the processes of citybuilding, infrastructure investment and socioeconomic development. ${ }^{(24)}$ A high level of accumulated resilience means citizens have access to basic services and infrastructure that protect them and provide them with the ability to cope and recover. Generally, this means having high-quality, reliable and well-maintained infrastructure and services at the city level, and a level of individual purchasing power and livelihood stability to allow investment in resilience at the household level (e.g. home and life insurance, transportation, savings etc.). Furthermore, and more importantly, in cities with a high level of resilience, these assets are assumed. For citizens, the fulfilment of these entitlements of civil protection is the product of political processes. High levels of accumulated resilience are facilitated by electoral pressures as part of democratic political systems in which governments are held to account by citizens through transparent, responsive and proactive governance structures. Accumulated resilience is, ultimately, the product of good governance.

While the Making Cities Resilient Campaign advocates for local governments to take action on DRR, it also places a strong emphasis on institution-building and local governance structures that make up the backbone of accumulated resilience. The campaign cities show a broad spectrum of experiences, with different balances of DRR and accumulated resilience characteristics making up the resilience "profile" for each city. Table 7, listing the factors that local governments see as particular milestones for their city, shows a heavy concentration on governance the institutions and community structures that underpin a transition to a more resilient city.

Cities in high-income countries tend to have higher accumulated resilience, a result of the fulfilment of entitlements over decades of development. They also have more resources for implementing sophisticated disaster risk management systems such as complex forecasting, monitoring and warning systems, regular in-depth hazard-mapping and large-scale 
infrastructure developments. This helps explain why highly developed cities tend to have very low numbers of disaster casualties, even when hit by unprecedented storms or floods.

In cities in low-income and many middle-income countries, the level of accumulated resilience tends to be lower. Citizens experiencing high inequality, urban poverty and livelihood insecurity are likely to have low individual and household purchasing power and reduced access to basic welfare services and infrastructures. In this context, DRR often remains a relatively low priority, constrained by infrastructural deficit, inadequate provision and distribution of essential services, low availability of risk information, and dysfunctional risk communication channels. Activities in low-capacity municipalities such as Moshi, Kisumu, Narok (Kenya), Siquirres and the cities in Pakistan have therefore focused on improvements to basic infrastructure, resources for emergency response when needed and a limited number of small-scale DRR projects.

In many low-capacity contexts, improvements to basic infrastructure and other development activities are recognized by cities as part of resiliencebuilding. This is interesting and significant because the concept of accumulated resilience is closely related to development, and pursuing development objectives will simultaneously be good for resilience. By reducing underlying risk factors, vulnerability can be reduced, in turn improving the quality of life and livelihoods for communities in normal times as well as their ability to cope and recover in disaster situations. This reflects the paradigm shift from viewing risk management from the perspective of short-term recovery and response towards a view of risk management as part of a long-term political commitment to vulnerability reduction.

The emphasis by local governments on mainstreaming DRR into urban development is partly a response to the understanding that resilience is about achieving development objectives. It means that hazard risks and vulnerabilities are taken into account in ongoing urban programming, so that the consideration of risk reduction measures becomes institutionalized as part of the normal operations of municipal departments. This is highly significant for those who identify the reduction of baseline vulnerability factors as a prerequisite to resilience. ${ }^{(25)}$ The importance of mainstreaming risk reduction and adaptation within wider sustainable development objectives is emphasized in the Hyogo Framework for Action. Integrating development objectives and disaster resilience is seen as particularly important in Batticaloa, which has suffered from major infrastructural deficits and deepened poverty as a result of ethnic conflicts (the civil war ended in 2009) and the impact of the 2004 tsunami. Responding to these development challenges has been viewed as an opportunity to reduce disaster risk, alleviate poverty and empower communities simultaneously, and participation in the campaign is intended to help Batticaloa work towards sustainable development more broadly.

\section{c. Resilience $=$ resistance + coping capacity + recovery + adaptive capacity}

By drawing on resilience literature and city evidence, we propose four components that make up a resilient city.

Resistance: the ability to reduce or avoid the impact of a hazard. It includes construction of risk-reducing infrastructures, risk-sensitive 
construction practices and land development, accurate forecasting, early warning, and evacuation strategies. Resistance is primarily the outcome of DRR activities.

Coping capacity: the ability of a city to avoid irreparable damage to the urban system from which it is unable to recover. A city with high coping capacity will experience hazard impact but it is able to continue normal functioning within a short period of time, without permanent damage to livelihoods, health or well-being. It is equally important at all scales, enabled both by the total level of accumulated resilience in the city as well as the effectiveness of preparedness measures. At the time of disaster, coping capacity depends on the effective delivery of emergency assistance and relief and access to essential services (and their capacity and quality). These rely on a responsive and well-structured emergency response system, with effective social infrastructures, adequate allocation of resources and stockpiling, clear channels of communication between relevant actors, and knowledge of respective actors' responsibilities to ensure effective collaboration. At the household level, coping capacity is enhanced by strong social networks (social capital) and a high level of awareness of emergency procedures.

Recovery: the period of reconstruction and rehabilitation following a disaster that is closely tied to coping capacity. Recovery is facilitated by the strength of local economies and the diversification of livelihoods. Effective recovery may require state intervention and support to provide necessary funding and resources. Careful governance of the reconstruction process is required to prevent capture by vested interests and ensure ethical, equitable rebuilding focused on local residents' needs.

Adaptive capacity: this is needed to ensure that past mistakes are not repeated and that cities can be flexible to changing conditions, by making changes to current policy and practice in order to improve resilience for the future. This is particularly important in the context of climate change. High adaptive capacity requires mechanisms for institutional learning, such as institutionalized channels that allow the latest scientific knowledge to feed into policy. Investment in hazard research is important, as is collaboration between all relevant stakeholders so that adaptation is coordinated and complementary across sectors and scales. Adaptive capacity is also a function of the wealth and resources available in the city, and requires proactive governance with sufficient political will to drive this.

These components provide an easily understood framework for what resilience means on a tangible level, and that can be applied at multiple scales from individual, household and community, to city and above. It seeks to incorporate all components of resilience, at all stages of the disaster "cycle", from pre-event preparations, resistance and ability to cope at the time of hazard impact, capacity for recovery after an event, and ability to learn and apply knowledge to improve system resilience in the future.

\section{HOW DOES RESILIENCE FIT INTO A WIDER FRAMEWORK OF SUSTAINABLE DEVELOPMENT IN CITIES?}

Over the last 10 years, there has been increasing academic interest in the potential for overlap and complementarity between risk reduction, 
resilience (and adaptation) and sustainable development. (26) Evidence from the campaign cities indicates that in many cases, new DRR activities are being integrated into existing environmental programmes. This is despite the fact that divides between development, climate change and disasters communities remain persistent within high level policy circles.(27) This indication of bottom-up integration is encouraging for those in favour of a mainstreamed approach to resilience-building, particularly those disheartened by the lack of leadership in this area at the global scale.

Many cities have integrated resilience with local environmental management; some have also committed to addressing global issues such as reducing greenhouse gas emissions. Some risk reduction activities have drawn on protective ecosystem services - for instance, mangrove protection or reconstruction and afforestation in Makati, Makassar and Bangkok. Some cities are maintaining natural barriers/defences such as sand dune reinforcement (e.g. Cape Town); mangrove plantations (e.g. Makassar); windbreak tree-planting (e.g. Kampala); afforestation to reduce flood risk (e.g. Pune, India); and slope protection to reduce landslide risk (e.g. Quito). Some city plans include commitments to sustainable development - for instance, the Thimphu structure plan and the citywide sustainability plans in San Francisco (Philippines), Cape Town and Santa Tecla. There are also examples of environmentally friendly forms of income diversification to stimulate household incomes and increase resilience, for example organic farming and eco-tourism in San Francisco (Philippines) and Albay.

The important link between resilience and sustainability has been summarized in a statement by Cutter et al.: "... an environment stressed by unsustainable practices may experience more severe environmental hazards."(28) Turner explains this with reference to the "checks and balances" that exist between human and environmental systems. He adopts a systems approach, arguing that vulnerability and risk are the products of imbalances between society and nature, and therefore environmentally sustainable practices are central to increasing overall system resilience. ${ }^{(29)}$ Resilience-building and vulnerability reduction are thus best approached as part of a wider agenda to improve the ability of cities to flourish within environmental constraints. The importance of mainstreaming risk reduction and adaptation within wider sustainable development objectives is emphasized in the Hyogo Framework for Action (priority areas one and four)

\section{CONCLUSIONS}

For city authorities seeking to enhance DRR, resilience is best seen as resistance + coping capacity + recovery + adaptive capacity.

Campaign city activities show strong evidence of mainstreaming DRR into their development plans and environmental management. This helps ensure that all four components listed above are addressed. DRR is not the whole story; much resilience comes from development and good governance as a political process (accumulated resilience).

There is a range of underlying risk factors in cities with low resilience - including large sections of a population lacking secure incomes and basic infrastructure and services, high levels of poverty, poor land use management and low political accountability for the provision of
26. See, for example, Schipper, L and M Pelling (2006), "Disaster risk, climate change and international development: scope for, and challenges to, integration", Disasters Vol 30, pages 19-38; also Turner, B (2010), "Vulnerability and resilience: coalescing or paralleling approaches for sustainability science?", Global Environmental Change Vol 20, pages 570-576; see reference 7; and Folke, C, S Carpenter, T Elmqvist, L Gunderson, C S Holling, B Walker, J Bengtsson, F Berkes, J Colding, K Danell, M Falkenmark, L Gordon, R Kasperson, N Kautsky, A Kinzig, S Levin, K-G Mäler, F Moberg, L Ohlsson, P Olsson, E Ostrom, W Reid, J Rockstroem, H Savenije and U Svedin (2002), "Resilience and sustainable development: building adaptive capacity in a world of transformations", Scientific Background Paper on resilience, for the process of the World Summit on Sustainable Development, on behalf of the Environmental Advisory Council to the Swedish Government, Stockholm, Sweden, 73 pages.

27. Evidenced, for example, by ICLEI's Third Global Forum on Urban Resilience and Adaptation (Resilient Cities 2012) and the UNFCCC'S Bonn Climate Change Conference being held simultaneously in May 2012, directly across the road from one another but with little or no interaction.

28. See reference 7, page 601. 29 . See reference 26 , Turner (2010). 
infrastructure and social welfare. As the Hyogo Framework of Action states, addressing them requires action across all sectors. Pursuing development objectives across multiple sectors as part of resilience-building is therefore very important. This mainstreamed approach will help to prevent resilience-building in one sector being offset by maladapted policies implemented in another, and helps to foster a culture of risk reduction being viewed as "everyone's responsibility".

We have yet to see which is the more effective means of getting DRR embedded in development: top-down from international support and national government leadership; or with cities starting resilience-building on their own and seeking support from either national government or overseas partners. Long term, it is clear that national level support is vital (e.g. South Africa and the Philippines) but good use of national support depends on competent, accountable local governments.

\section{REFERENCES}

Cutter, S, L Barnes, M Berry, C Burton, E Evans, E Tate and J Webb (2008), "A place-based model for understanding community resilience to natural disasters", Global Environmental Change Vol 18, pages 598-606.

Da Silva, J, M Moench, S Kernaghan, A Luque and S Tyler (2010), "The Urban Resilience Framework (URF)", ISET and ARUP, 4 pages.

Folke, C, S Carpenter, T Elmqvist, L Gunderson, C S Holling, B Walker, J Bengtsson, F Berkes, J Colding, K Danell, M Falkenmark, L Gordon, R Kasperson, N Kautsky, A Kinzig, S Levin, K-G Mäler, F Moberg, L Ohlsson, P Olsson, E Ostrom, W Reid, J Rockstroem, H Savenije and U Svedin (2002), "Resilience and sustainable development: building adaptive capacity in a world of transformations", scientific Background Paper on resilience, for the process of the World Summit on Sustainable Development, on behalf of the Environmental Advisory Council to the Swedish Government, Stockholm, Sweden, 73 pages.

Holling, C S (1973), "Resilience and stability of ecological systems", Annual Review of Ecology and Systematics Vol 4, pages 1-23.

http://www.unisdr.org/we/inform/gar.

http://www.unisdr.org/we/inform/publications/28240.

IFRC (2010), World Disasters Report 2010: Focus on Urban Risk, International Federation of Red Cross and Red Crescent Societies, Geneva, 220 pages.

Klein, R, R Nicholls and F Thomalla (2004), "Resilience to natural hazards: how useful is this concept?", EVA Working Paper No 9, DINAS-COAST Working Paper No 14, Potsdam Institute for Climate Impact Research, Germany, 7 pages.

Lewis, Dan (2013), "Urban resilience: from advocacy to implementation", Presentation to the UN-Habitat session at the UNISDR Global Platform for Disaster Risk Reduction, 22 May 2013, Geneva.
Oliver-Smith, Anthony (2011), Defying Displacement: Grassroots Resistance and the Critique of Development, University of Texas Press, Austin, 316 pages.

Pelling, Mark (2003), The Vulnerability of Cities: Natural Disasters and Social Resilience, Earthscan, Abingdon, 212 pages.

Satterthwaite, David (2013), "The political underpinnings of cities' accumulated resilience to climate change", Environment and Urbanization Vol 25, No 2, pages 381-391.

Schipper, L and M Pelling (2006), "Disaster risk, climate change and international development: scope for, and challenges to, integration", Disasters Vol 30, pages $19-38$.

Smit, B, O Pilifosova, I Burton, B Challenger, S Huq, R Klein and G Yohe (2001), "Adaptation to climate change in the context of sustainable development and equity", in J J McCarthy, O F Canziani, N A Leary, D J Dokken and K S White (editors), Climate Change 2001: Impacts, Adaptation and Vulnerability, Contribution of Working Group II to the Third Assessment Report of the Intergovernmental Panel on Climate Change, Cambridge University Press, Cambridge, pages 877-912.

Turner, B (2010), "Vulnerability and resilience: coalescing or paralleling approaches for sustainability science?", Global Environmental Change Vol 20, pages 570-576.

UNISDR (2009), Global Assessment Report on Disaster Risk Reduction: Risk and Poverty in a Changing Climate, Geneva, 207 pages.

UNISDR (2011a), Revealing Risk, Redefining Development: The 2011 Global Assessment Report on Disaster Risk Reduction, Geneva, 178 pages.

UNISDR (2011b), Taking Stock of Progress and Future Strategy on the Resilient Cities Campaign: Summary of Responses from Partners, Report on feedback from ICLEI, EMI, UN-Habitat, Asia RTF-URR, ADPC, WCSDA, RMIT, GROOTS International, provided by UNISDR, May 2012, 7 pages. 
UNISDR (2012a), How to Make Cities More Resilient: A Handbook for Local Government Leaders, United Nations, Geneva, 102 pages.

UNISDR (2012b), Making Cities Resilient Report 2012: A Snapshot of How Local Governments Reduce Disaster Risk, 116 pages, available at http://www.unisdr. org/we/inform/publications/28240.

UNISDR (2013a), From Shared Risk to Shared Value; the Business Case for Disaster Risk Reduction. Global
Assessment Report on Disaster Risk Reduction 2013, Geneva, 246 pages and annexes.

UNISDR (2013b), "Toolkit for local governments - 10 essentials", accessed 9 December 2013 at http://www. unisdr.org/campaign/resilientcities/toolkit/essentials.

Wisner, Ben, Piers Blaikie, Terry Cannon and Ian Davis (2004), At Risk: Natural Hazards and People's Vulnerability, second edition, Routledge, New York, 447 pages. 